Relations industrielles

Industrial Relations

\title{
Franzosi, Roberto, The Puzzle of Strikes: Class and State \\ Strategies in Postwar Italy
}

\section{Martyn Wright}

Volume 51, numéro 1, 1996

URI : https://id.erudit.org/iderudit/051086ar

DOI : https://doi.org/10.7202/051086ar

Aller au sommaire du numéro

Éditeur(s)

Département des relations industrielles de l'Université Laval

ISSN

0034-379X (imprimé)

1703-8138 (numérique)

Découvrir la revue

Citer ce compte rendu

Wright, M. (1996). Compte rendu de [Franzosi, Roberto, The Puzzle of Strikes: Class and State Strategies in Postwar Italy]. Relations industrielles / Industrial Relations, 51(1), 219-220. https://doi.org/10.7202/051086ar

Tous droits réservés (C Département des relations industrielles de l'Université Laval, 1996
Ce document est protégé par la loi sur le droit d'auteur. L’utilisation des services d'Érudit (y compris la reproduction) est assujettie à sa politique d'utilisation que vous pouvez consulter en ligne.

https://apropos.erudit.org/fr/usagers/politique-dutilisation/ 


\section{The Puzzle of Strikes: Class and State Strategies in Postwar Italy}

by Roberto FRANZOSI, Cambridge, Cambridge University Press, 1995, 502 p., ISBN 0-521-45287-2.

This is an ambitious work which operates on a number of levels. On one level, it is an investigation into strike patterns in postwar Italy. Competing theories of industrial action are set out and tested on the available Italian evidence. On another level, the book ranges far more widely than the title might suggest. It is in part an instruction in the economic and political organization of Italian industry, and in the history of Italian postwar politics. But it is also a political economy of the generation and regulation of industrial conflict in advanced capitalist societies, with Italy as the case study.

For the most part, the work maintains a high level of analytical and methodological sophistication. The main theoretical approaches are examined with advanced statistical techniques. These include the Ashenfelter and Johnson model of bargaining power, resource mobilisation theories and structural features of the Italian labour market and collective bargaining. There is also a study of social influences such as class conflict and political power and their impact upon industrial action. Finally, anomalies in strike patterns, such as the 1969 autumno caldo strike wave, and the responses of employers and the state to this, are explored.

One of the especially pleasing features of the work is the way which quantitative and qualitative data, and statistical and historical perspectives are juxtaposed. This is an analytical style which the author maintains throughout, and it is highly effective. Chapter 3 , for example, includes an econometric evaluation of the applicability of the Ashenfelter and Johnson model to the Italian case, and of the significance of plant size and occupational structure. But these findings are contextualized with a history of the social and technological organization of the
Italian workplace, interspersed with narrative accounts of Italian workers' experiences of strikes.

A key outcome of this approach is that suggested causal explanations are sensitive to theories drawn from a range of disciplines. Economic variables such as real wages and unemployment are interweaved with social phenomena, such as the cultural consequences of the migration of workers from the South to the manufacturing strongholds of the North. This approach also enables Franzosi to show how the dynamics of conflict are shaped by management-labour interactions. For example, the autumno caldo impacted upon the political landscape and management policies in a way that changed the nature of subsequent strike action in Italy.

Combining advanced statistical analysis with narrative and historical material does create difficulties. The bulk of the quantitative material is condensed into the earlier chapters, which in parts are highly technical and demanding to read. There is much discussion of the procedures of statistical analysis, such as residuals and outliers. A series of lengthy formulae interrupt the text. This tends to distract the reader from the arguments which are being constructed. More rigorous editing would have been of benefit here, with the statistical descriptions placed in footnotes or an appendix.

The latter half of the book, by comparison, is engrossing. These chapters generally eschew quantitative testing of theories and scrutinize the organizational and processual aspects of collective organization. Chapter 7 is a fine example of this. It deals with the 1969 strike wave. It shows how the initiative in the strike shifted from established skilled workers to the unskilled, young migrants from the South. The forms of collective action 
employed are detailed, such as rotating strikes between different departments in a plant. And the margins of collective organization, which did not extend to large areas of the country, to smaller firms or to white collar or technical workers, are traced.

An additional point refers to the structuring of the volume. The book is organized as a continuing narrative, what Franzosi refers to as 'my story' (p. 348). With the exception of the opening and closing chapters, each chapter takes up what remains unexplained from its antecedent. This allows a single theme to be developed incrementally at length, which is a commendable aim. But it is difficult to read the chapters out-of-sequence, or as self-contained pieces. This limits the book's usefulness for teaching purposes. It would also have been beneficial for the explanatory model, which is introduced only in the final chapter of the book, to have been described at the outset. In this way, the model might have been compared to the competing theories which are variously tested.

It is a theoretically challenging work. Franzosi advances an explanatory model which is founded upon the French Régulation and the American social structure of accumulation schools of social thought. It is a neo-Marxian account of the reciprocity between social conflict and the institutional mechanisms that regulate it. This is the basis of a profound explanation. But it is not fully satisfying. The foundational elements of the model accumulation, class conflict, class structure and economic/political organization need to be expanded. As a result, the model, as set out in the text, is insufficiently detailed to provide the clinching argument that is required. There is great potential to develop further this thesis.

MARTIN WRIGHT The University of Warwick

\section{La sociologie des entreprises}

par Philippe BERNOUX, Paris, Éditions du Seuil, 396 p., ISBN 2-02-023632-X.

Depuis la publication en 1985 du volume Sociologie de l'organisation, le sociologue français Philippe Bernoux a permis à plusieurs lecteurs, étudiants, professeurs et praticiens de s'initier à la sociologie des organisations par cet ouvrage didactique et érudit sur un sujet fort complexe et mouvant, l'organisation du $\mathrm{XX}^{\mathrm{e}}$ siècle. Cette fois, l'auteur publie un volume fort relevé sur la sociologie des entreprises qui complète en même temps qu'il marque une rupture avec les organisations comme objet sociologique. En effet, nous dira l'auteur, la sociologie des entreprises prend le relais de la sociologie du travail et de celle des organisations. Mais elle rompt avec celles-ci parce que l'objet en est renouvelé, le champ d'étude se distinguant des objets sociologiques précédents.

Mais il ne suffit pas de le dire, encore faut-il que l'objet soit construit de façon convaincante. D'autant plus que la notion de sociologie de l'entreprise a cours essentiellement dans la sociologie française. Ailleurs, principalement dans le monde anglo-saxon, la sociologie des organisations tient encore lieu de domaine d'étude et d'analyse des lieux de production et de coordination d'activités humaines, il sera question d'organisation " post-moderne", pour bien distinguer les transformations en cours, qui se démarque de l'organisation bureaucratique. Outre cette distinction dénominative, l'objet est-il le même? Après tout il existe bien une "sociologie industrielle", notamment aux États-Unis, qui n'a jamais eu d'écho en France. Philippe Bernoux expliquera que l'entreprise est un objet sociologique en rupture avec l'organisation depuis le début de la décennie 80 où l'on assista d'abord à son " réenchantement " suite à la crise économique. Puis les travaux précurseurs de Renaud 